\title{
Gender Difference in the Roles Performed by Project Stakeholders in Poverty Reduction Projects in Baringo North Sub- County
}

\author{
Lilian R. Chesikaw \\ Institute of Women, Gender and Development Studies, Egerton University, Njoro, Kenya
}

Email address:

lchesikaw@yahoo.com

To cite this article:

Lilian R. Chesikaw. Gender Difference in the Roles Performed by Project Stakeholders in Poverty Reduction Projects in Baringo North SubCounty. Humanities and Social Sciences. Vol. 4, No. 6, 2016, pp. 140-147. doi: 10.11648/j.hss.20160406.12

Received: September 13, 2016; Accepted: September 23, 2016; Published: October 27, 2016

\begin{abstract}
Poverty has become and continuous to be a key word in many developing countries and it is central to International Development Policy. A huge amount of money is spent on projects in the quest for poverty reduction and lots of expertise continues to be offered to try and address poverty, yet there is nothing much to show for it. This study intended to establish gender difference in the roles performed by project stakeholders in poverty reduction projects in Baringo North Sub- County. The Study was carried out in Kipsaraman and Bartabwa administrative Wards and focused on projects that have been set up by the Government of Kenya and Non-Governmental Organizations whose objective is to address issues of poverty. It was established in this study that the level of participation in the projects by women is significantly low compared to that of males which is nearly one-half times that of the females. The study recommends that all community members irrespective of gender be allowed equal opportunity to be actively involved poverty reduction project. The study suggests that a similar study could be replicated in other counties to be able to unpack challenges in project.
\end{abstract}

Keywords: Gender Difference, Project Stakeholders, Poverty Reduction Projects

\section{Introduction}

Many countries are faced with challenges of poverty and consequently the support from various organizations in form of development projects is important. In Kenya, like many parts of the world, more women than men suffer the effects of poverty. In Baringo County which was the focus of this study, the same scenario is replicated. This is made worse by the fact that it is an Arid and semi-Arid county (ASAL), and equally one of those areas that have been marginalized by development Agencies and Governments for many years. It was ranked 49th in national poverty levels. Out of a population of 111,093 in Baringo North, an estimated 48,274 are poor, majority of who are women and girls. Food poverty stood at 50 per cent (Baringo Demographic Profile, 2008). They faced a myriad challenges including, low levels of education, insecurity, harmful cultural practices like FGM, early marriages, gender discrimination in access to resources, male favouritism, unequal gender relations among others.
The Government of Kenya has put in place various interventions aimed at reducing poverty. Some of them include micro-credit programmes like the Women Enterprise Development Fund (WEDF) and Uwezo Funds (UF) Women Finance trust to help women borrow money to start up small scale income generating activities, Constituency Development Fund (CDF) to help fund projects, Free Education for All, lowering of entry marks for girls to the university.

Other interventions include the introduction of one third positions for women in government institutions, including the political domains through Affirmative Action. Recently free maternity for women and thirty per cent reservations in government tender procurement contracts to women, and youth and Persons Living with Disability (PLWDs) were introduced in Kenya as a way of reducing poverty. The Social Security Programme to help support old people. The program is being implemented by the Ministry of Devolution is also on-going. There is also the National Youth Service Programme being implemented; recruiting youths to work on community programmes, is on-going as a way of reducing 
poverty.

Non-Governmental Organizations (NGOs) and Faith Based Organizations (FBOs) too have done a lot in trying to reduce poverty by initiating various development projects. Some of the development projects include construction of schools, hospitals, provisions of scholarships for needy children, small business startups and nutritional skills among others. Many people in those areas benefited immensely through accessing drugs in hospitals and better health services. That helped to lower child and maternal deaths and improved nutritional health.

Other NGOs like World Vision and Action Aid have helped the community with training opportunities and drilled water. They have also played an immense role in food security by enhancing diversification of food. This has resulted in good nutrition and children's' health. Some community members benefited also through training in management skills entrepreneurial skills and on other development issues which helped them to make informed choices when running their activities and earning profits that contributed to poverty reduction. Some people benefited from these organizations by acquiring tangible products. Some were given cows to share among themselves and trained on good animal husbandry; others were given seeds to plant improving food security. Others have drilled water for people and animals to use.

Despite efforts made by the various stakeholders, many of these development projects did not achieve greater success because of various social, cultural, political and economic reasons. Noteworthy, most of these development projects did not target women directly and the trickledown assumptions effect did not therefore bear the expected results. The women's low levels of education have been a hindrance to their full participation in these projects, the credit conditions are far beyond the reach of many poor women, lack of adequate training has also been a set back to their progress. Majority of the women have no procurement and tendering skills and are often faced with the challenges of with limited resources.

\subsection{Research Objective}

To determine gender difference in roles performed by the project beneficiaries in poverty reduction projects in Baringo North Sub- County from a gendered perspective

\subsection{Research Hypothesis}

H0: There is no statistically significant relationship of the types of roles performed by the project beneficiaries in the projects in Baringo North Sub-County on the basis of their gender.

\section{Literature Review}

\subsection{Roles in Poverty Reduction Projects}

Goetz (1995) observed that women's interests in the definition of policies face deep bureaucratic resistance which exists with regard to the equitable integration of women as subjects of public policy. Public institutions that enforce and apply rules and regulations reflect and reproduce the values, norms and biases of the societies in which they are immersed and that includes notions about masculinity and femininity. According to Longwe (1997), the state is responsible for formulating policies and programmes and coordinating resource allocation equally for both the female and male populations.

Bachelet (2010) emphasized the role of the government in poverty reduction. She reiterates that "where there is poverty, the government cannot be neutral. It is the government's responsibility to provide permanent social protection and to reduce the inherent social weaknesses. The State has to guarantee people's rights, especially for the most vulnerable and the people who are living in the most difficult situations. We need to develop focus while diminishing poverty which in so many places has a woman's face".

Foeken (2008) claims that one of the big problems affecting poverty reduction is the fact that policy formulation and implementation follow an iterative process. This is a process whereby ideas and theories inform policies, whose implementations lead to results of which their evaluation and analyses give rise to new insights, new policies and new results. On another level, NGO and donor development policies are increasingly dependent on the ideas of those offering financial aid. Poverty reduction policies have entrenched a cycle of starting projects, evaluating them, manufacturing ideas and formulating new policies.

\subsection{Poverty Reduction Projects in Kenya}

The government introduced UWEZO Fund, Kenya Women Finance Trust to reduce poverty among women and youths. Many women and youth groups have benefited from the funds and are changing their lives and those of their family members. However, the study found out that some of the groups did not access the funds because the conditions for their access were hard for them to achieve, so they had to miss out. One of those deterring conditions was to have a running bank account with $30 \%$ amount of the expected money, which the youth could not have.

The revival of the National Youth Service Programme was an initiative to alleviate poverty. This programme is on-going in many parts of the country where youths are engaged in many development activities and get paid for it by the Government. That has greatly helped to change the lives of the jobless youths who are using their time in profitable activity and earning income. This noble programme has been riddled by corruption and many youths are now facing desperation of joblessness.

The government and non-governmental bodies have embarked on drilling of boreholes in various parts of the country to ensure that Kenyans access water for their use and many irrigation projects have come up based on that input. For example in Tan River, Kerio Valley, Turkana and Samburu, just to mention but few. However, there is no much attention given to them on budgetary allocations and the communities in those places have to carry out their activities with their own 
efforts. More so those boreholes are few and many places do not have water. Other initiatives include development of road infrastructure, enhancement of education access and provision of free medical services.

The government formulated the Economic Recovery Strategy Paper 2003 as the blueprint meant to guide the Government's economic policies over the next five years. The Government placed economic recovery on top of its policy agenda in order to reverse decades of slow and in some cases stagnating economic growth that has adversely undermined the well-being of Kenyans (GoK, 2004). The overall objective of the strategy plan was to harmonise strategies for accelerated economic growth with the country's poverty reduction strategies. In the strategy, the government proposed the following Poverty Targeted Programs: The Social Action Fund, Arid and Semi-Arid Lands, Slum Upgrading and low-costing Housing, Vulnerability Program and Investment Programme (Gondi, 2005).

The government came up with The National Poverty Eradication Plan (NPEP) 1999-2015. The plan presented a vision for the early 21 st century when Kenya hopes to halt the current increase in the incidence of poverty and then eradicate it step by step on the grounds of sound economic principles that recognize the critical role and the potential contribution of the poor to national development. The aim of NPEP is to provide a national policy and institutional framework for action against poverty. NPEP was formulated through extensive consultations and participatory action involving civil society, NGOs and Government agencies, (Neru \& Alila, 2005).

The plan has three major components from which a framework for further action is set by the government, civil society, and private sector and other development partners. These components include social integration, improved access to essential services by low income households that currently lack basic health, education and safe drinking water and a Strategy for broad based economic growth. The implementation plan was expected to cover the period 1999-2015. The plan had strategies such as; Urban Slum Development of Nairobi, Land Resettlement Programmes, Street Children's Fund, Constituency Education Bursary Fund, Constituency Development Plan, Women development enterprises and Youth programmes (Omiti, 2002), all that were aimed at alleviating poverty.

Poverty Reduction activities and projects in Baringo County have been some of the key approaches in changing people's vulnerable situations and bettering lives. North Baringo Sub-County too has many such projects aimed at reducing poverty and this research will be able to unpack the impacts of such projects.

\section{Research Methodology}

A simple randomized ex-post facto design was adopted in this study to investigate and analyze the research problem. Ex post facto design is a form of survey research where independent variables are selected rather than manipulated and observations and analyses of relationships among the variables are carried out in their natural settings (Kathuri \& Pals, 1993). The study used both qualitative and quantitative data and consequently adopted both quantitative and qualitative techniques.

The Study was carried out in Kipsaraman and Bartabwa administrative Wards. The study focused on projects that have been set up by the Government of Kenya and Non Governmental Organizations whose objective is to address issues of poverty. The target population of the people estimated to be poor is 48,274 translating to $46 \%$ of the total population. Thirty percent of the population (1800 households) were drawn from the two selected divisions in the district to constitute the sample frame. According to Kerlinger (1983), ten parent of the sample size in social science was allowed and randomly selected as the sample size of study. 180 households for the two divisions were therefore used for the study.

The study used both self-administered schedules and questionnaires. The questionnaires contained both structured and unstructured questions for the sake of obtaining quality information. Interview Schedule was developed after the review of relevant secondary data. They composed of 8 open ended questions. These were questions that asked for unprompted opinions with no predetermined set of responses and the participants were free to answer however he/she chose. The interview schedule was administered to 180 households of Baringo North Sub-county. Most of the questions measured a single variable or opinion. Focused group discussions were also conducted by the researcher with five groups of seven community stakeholders.

The collected data was coded with regard to the type and source. It was analyzed and interpreted quantitatively in the light of the research objectives. Qualitative data was coded according to themes (Buzan, 1995). Coding was used in the current study as a means of identifying themes within the interview notes. The findings of the study were presented in the form of tables.

\section{Findings}

\subsection{Project Initiators}

Table 1. Project Initiators.

\begin{tabular}{lll}
\hline & Frequency & Percent \\
\hline Locals & 61 & 35.3 \\
NGO's & 35 & 20.2 \\
GOK & 51 & 29.5 \\
Church & 20 & 11.6 \\
Other e.g. CDF, Governor, Individual Sponsor & 6 & 3.5 \\
Total & 173 & 100.0 \\
\hline
\end{tabular}

Results from table 1 show that about $35.3 \%$ of the projects in the study area were initiated by the locals followed by the Government of Kenya (29.5\%) and NGOs (20.2\%) in that order. The church and others such as Constituency Development Fund (CDF) and governor (county government) have been able to contribute $11.6 \%$ and $3.5 \%$ respectively. 
Initiation by the local community is in line with the harambee (common effort) spirit of the Founding president of Kenya, Jomo Kenyatta. In this philosophy, it is common for the local people to come together and combine efforts in order to solve a problem that is bedeviling them for the common good of the society they live in. Through the harambee spirit the community was able to initiate projects to alleviate their poverty levels and to be able to take their children to school.

It is regrettable, however, to note that the devolved system of governance through CDF funding had not been felt on the ground owing to the $4 \%$ of the respondents who claimed to be aware of this. However, this may be attributed to lack of public awareness about these projects or that the CDF projects could be few and not well distributed to be seen and felt by the community. Considering the fact that CDF has been around in Kenya for a considerable length of time and if it was being implemented through projects then its impact should have been felt and seen by the local community, which was not the case in the study area. The devolution process at the time of this research might not have been fully implemented and this might be used to explain the meager percentage on community and County Government funding, therefore any poverty reduction projects were funded through $\mathrm{CDF}$ or other Development partners. Observations showed no much impact of the projects in the area. With the full implementation of devolution, the county government should therefore make concerted efforts of creating public awareness and involve the community actively in some of the projects that are being initiated.

\subsection{Reasons for Project Initiation}

Table 2. Reasons for Project Initiation.

\begin{tabular}{lll}
\hline & Frequency & Percentage \\
\hline Poverty levels & 3 & 43 \\
Community problem & 1 & 14 \\
Illiteracy /enhancing knowledge & 2 & 29 \\
Helping sick & 1 & 14 \\
Total & 7 & 100 \\
\hline
\end{tabular}

It is evident from table 2 that most projects were started with the aim of alleviating poverty (43\%), reduction of illiteracy (29\%), solving general community problems and helping the sick each at $(14 \%)$. This observation is consistent with the interview information gathered from the District Development Officer (DDO) who attested to the poverty levels in the district were so high with $47 \%$ men and $53 \%$ women living below the poverty line. The DDO further attributed the high number of poor women in the district to factors such as; harsh climatic conditions, migration of professionals from the community, cultural norms that impact women negatively in access to wealth and inheritance of property, high illiteracy levels, lack of employment and insecurity especially in Bartabwa Ward.

Indeed, the findings confirm the KNBS (2009) findings which also observed that nearly $46 \%$ of the population in Baringo County live in abject poverty. This is perhaps one single most reason why most projects in the area are geared towards addressing poverty concerns so as to improve the livelihoods of the people. The observation was that many people survived on one meal a day and others would even survive on one meal in two days especially, around the Bartabwa area where there were many challenges that have driven people to greater poverty.

Many of those challenges were contributed by different factors, for instance the high illiteracy levels of women was based on the cultural beliefs and practices of the community that hindered them from accessing to education. For example, the community valued the boy child and preferred sending them to school as opposed to the girls whom they saw as peoples' wives and no need to waste family resources in educating them since they would benefit other people. The girls were married off early in order to fetch dowry to educate the boy child and subsidize the family income.

Research has shown that there are many benefits accruing to the society from an educated woman including poverty reduction, since family members' lives depend on the contributions of women as their handlers, care givers and nurturers, and once a woman is poor, it affects everyone irrespective of their gender (World Bank 2002). Other negative practices also included Female Genital Mutilation the girls go through at an early age, prompting them to be married off early, hence dropping out of school. There were also challenges of rampant early or unwanted pregnancies which made many girls drop out of school.

According to Tugen culture, women are forbidden from property inheritance and control of resources and not allowed to make decisions and that causes the high rates of poverty especially, among the women. Those challenges also contribute to gender inequalities and intersect with poverty to perpetuate and sustain high levels of poverty in Baringo North Sub-County. The harsh climatic conditions in the Semi-Arid areas was a huge hindrance to the progress of women who had to struggle to get food for their families, walked long distances in search of water and firewood. This kind of work takes much of women's time took and therefore cannot get time to go to school to empower themselves and this increases poverty in that community.

Another contributory factor to poverty levels was the absence of educated professionals from the area who moved away to places where they would get better lives for their families, leaving their villages without contributing much to change and to serve as role models to their communities and that has contributed to poor development levels of the area. Many of the youths who have completed their secondary education and who attained professional certificates are jobless. They have become a liability to the community since they idle around trading centres, participating in taking cheap and illegal alcohol and living hopeless lives. They also engage in illegal activities like robbing people, becoming a security threat. Many families have been reduced to abject poverty after spending their meager resources in the education of their children, who end up not accessing job opportunities in order to add value to the lives and those of their families.

Insecurity in Bartabwa ward had reduced families to paupers 
after losing their livestock to cattle rustlers from the neighbouring communities who kill and maim at will and drive away their livestock, leaving them destitute. Many of the families have been displaced and some lived in camps and others in bushes at the time of this research. A considerable number of schools had been closed down owing to insecurity and livelihoods also destroyed escalating poverty in those areas.

\subsection{Project Sponsors}

Table 3. Project Sponsors.

\begin{tabular}{lll}
\hline Sponsor & Frequency & Percent \\
\hline NGOs & 48 & 27.7 \\
Church & 29 & 16.8 \\
Community & 38 & 22.0 \\
GOK & 51 & 29.5 \\
Others-Governor, CDF etc & 7 & 4.0 \\
Total & 173 & 100.0 \\
\hline
\end{tabular}

As can be observed from table 3 , the role of community and non-governmental organizations cannot be understated. Most of the projects in the area are sponsored by the government of Kenya (29.5\%) and NGOs (27.7\%) followed by the community in which the projects are located $(22 \%)$ while the church and others like CDF contribute about $20.8 \%$. These findings may be a pointer to the fact that project initiation in terms of formulation and implementation require an immense amount of resources especially financial aspect that is why the two bodies (government of Kenya and the Non-governmental organizations) who are known to be well-endowed with financial resources were way ahead of the rest in terms of sponsoring the projects.

There is also an indication that the other groups especially the CDF has not done much considering the financial allocation since its inception fifteen years ago. It is very encouraging to see that the community puts a lot of effort in trying to bring themselves out of poverty. Several bodies promoting poverty reduction should support the efforts of the community by investing in more projects in the area. There is also the need for more and constant engagement with GoK and the NGOs in order to increase their financial support and initiate more Poverty Reduction Projects.

The current findings are in agreement with the information given by the District Dvelopment officer (DDO) regarding sponsors involved in poverty reduction projects in the study area. According to the DDO, various groups involved in sponsoring projects include: NGOs, the government, community through women and youth self-help groups (SHGs) and the church.

\subsection{Project Sector Sponsorship}

Table 4. Project Sector Sponsorship.

\begin{tabular}{lll}
\hline Project sector & Frequency & Percentage \\
\hline Health & 3 & 50 \\
Environment & 1 & 17 \\
Education & 1 & 17 \\
Animal husbandry/livestock & 1 & 17 \\
\hline
\end{tabular}

The findings in table 4 indicate that specific projects that the target beneficiaries were involved in included: poultry business, vegetable business, rearing of cattle, and planting trees among others. It is worth noting that the target group beneficiaries were aware of and participated in most development projects that were being implemented in the target area. These findings are similar to those of Njeru and Wainaina (2005) who found that the success of any project is determined by the level of awareness of projects' existence by beneficiaries which included the community in which the projects were being carried out.

\subsection{Role in Project Planning and Implementation}

Table 5. Role in Project Planning and Implementation.

\begin{tabular}{lll}
\hline Dimensions & Frequency & Percent \\
\hline Formulation & 16 & 9.2 \\
Implementation & 88 & 50.9 \\
Idea Contribution & 46 & 26.6 \\
Guiding Implementation & 8 & 4.6 \\
None & 5 & 2.9 \\
Others e.g Target group ignored & 10 & 5.8 \\
Total & 173 & 100.0 \\
\hline
\end{tabular}

As can be observed from table 5, majority of the respondents $(50.9 \%)$ were involved during project implementation, idea contribution $(26.6 \%)$, and project formulation $(9.2 \%)$ while others were involved in guiding the process of implementation (4.6\%). Interestingly however, a small proportion $(5.8 \%)$ of the respondents felt that they were ignored from participating in any phase of the project development while another $2.9 \%$ of the participants participated in none. It is therefore evident that to a large extent, there was a high rate of stakeholder participation $(91.3 \%)$ in the projects that are implemented in Baringo County.

However, the figures above show where they are concentrated-at the implementation level. It is common knowledge that priorities in any project are set at the formulation level. In the projects of Baringo North Sub-County, majority of the community members were not involved at the formulation level of projects. That is a critical stage where everyone's views are accommodated in order to make the projects more acceptable and creates trust and confidence. At the implementation level, the figures above show that many people participated but that did not mean that their voice was included in what they were implementing so in essence they were implementing other people's ideas and that might have contributed to the poor performance of some of the projects especially, government projects that stalled. Most of those projects took an up-bottom approach where the communities were given instructions on what should be done by those in authority.

The target group that felt was ignored raised a very pertinent issue. In the study area, the norm was that many of the projects were run by men including the ones that targeted women. It was an occurrence that was observed in many areas, 
especially in regard to projects meant for women. In fact there were some women groups which had men in them as members and when asked why, the women said that they helped them with advice on how best they could run the affairs of their groups especially finances. In many of the women projects men took a front lead and were consulted before the women themselves and the activities would follow what the men deemed okay for the women. The women would just be explained about what had been decided so theirs was to rubber stamp those decisions. Their ignorance had been occasioned by their high illiteracy levels and they were seen as people who had no much capacity and needed help in making informed choices concerning projects.

That could suggest that the people of Baringo North Sub-County uphold African culture that women should be ruled by men and should implement their decisions and the women had no option but to obey. The women were also socialized to believe that men were their leaders and whatever they said was right and had to be followed. It could also mean that some people who first got information on projects took an upper hand in the projects in their quest to benefit from them before others could. In fact as mentioned earlier, the meaning of participation for many people did refer to managing projects or making decisions on them. Many community members especially women would attend meetings and they interpreted it to mean implementation or participation.

From the discussions with the target group members, they blamed the process of managing projects based on top-down decisions. They said that even if they were poor, illiterate or assumed not to know anything, they knew what was best to solve their problems and how to do it. It therefore came out from them that, their lack of involvement was one of the main reasons why government projects stalled since they lacked ownership.

\subsection{Gender Disaggregation in Role in Project Planning and Implementation}

Table 6. Gender Disaggregation in Role in Project Planning and Implementation.

\begin{tabular}{lllllll}
\hline \multirow{2}{*}{ Gender } & \multicolumn{5}{l}{ Role of target group in the planning and implementation of the project } & \\
\cline { 2 - 7 } & Formulation & Implementation & Idea Contribution & Guiding Implementation & None & Others e.g Target group ignored \\
\hline Female & $7(5 \%)$ & $19(13 \%)$ & $19(13 \%)$ & $4(3 \%)$ & $9(6 \%)$ & $3(2 \%)$ \\
Male & $9(6 \%)$ & $42(29 \%)$ & $19(13 \%)$ & $6(4 \%)$ & $5(3 \%)$ & $2(1 \%)$ \\
Total & $16(11 \%)$ & $61(42 \%)$ & $38(26 \%)$ & $10(7 \%)$ & $14(9 \%) 5(3 \%)$ \\
\hline
\end{tabular}

It can be observed that gender plays a great role in the planning and implementation phases of the development projects in the Sub-County. Notably a significant majority of men $(29 \%)$ were involved in project implementation compared to that of women (13\%). Similarly more men (6\%) were involved in formulation of the project compared to women (5\%). Similar observations can be noted in participation in project guidance during implementation where men form (4\%) of the total while females constituted $3 \%$ of the total number of respondents.

Interestingly though, there appeared to be an equal representation for both gender in terms of idea generation which stood at $13 \%$. That was based on the decisions made in public meetings where both genders attended. In such meetings, people are given briefs by the sponsors or their representatives and community was asked if they agreed which they would affirm with a show of hands. This in turn would be translated to mean the decisions of the stakeholders.

A keener scrutiny of the results show that about $2 \%$ of the women in the study area reported being ignored compared to their $1 \%$ male counter parts. The more number of women than men not involved in the projects meant that the community did not trust so much the capabilities of women. Their culture also did not allow women to participate in public domain issues. Moreover, many of them did not go to school, so they were assumed not have ideas that could add value to the projects. That made them to miss out of the benefits accruing from the projects and hence continued to remain poor. Furthermore, $6 \%$ of the women folk did not participate in any phase of the project development process against 3\% men. That was appalling since most of the projects were meant to reduce poverty in the community, majority of who were women.

It gets even worse if the $6 \%$ are added to the $3 \%$ of women who were ignored in the projects because their percentage increased to $9 \%$ compared to the men with $3 \%$ in total. That reflected the gender inequality and explains the reasons why poverty persisted among the women folk. It also showed that many projects in Baringo North sub-County were not initiated based on gender. It also portrayed the disadvantage existing within projects that are not gender sensitive. Many women were relegated to their household chores, while men handled projects and the benefits did not trickle down to the women and children, majority of whom bore the brunt of poverty.

This was evidently shown in the findings where in total $34 \%$ of the women actively participated in various phases of project development while $54 \%$ of the male played an active role in the projects. Considering the areas where each gender concentrated their participation in the projects' activities, it was apparent that fewer women than men took part in them. For example, at every level of project activities as shown above women were fewer than men and that disparity was more pronounced at the implementation than at any other level.

The crucial level of the project was the implementation level since it was the level where benefits were attained yet majority of the women were missing out. They stood to benefit less since they merely relied on the decisions of the men on who should get what and how much. 
However, their numbers paralleled when contributing the ideas which according to the discussion with the target groups was done during public Barazas (public meetings). As explained earlier, what happened in Barazas, was that the community members attended and they would affirm what was being fronted by the project donors with a show of hands and that would be assumed as the true view of the people. Many times the community members' rubber stamped what was already decided by the donors of the projects since they needed the help.

Another disheartening observation was the percentage of $8 \%$ of the women who were either ignored or did not participate in the project as compared with that of the men of $4 \%$. That portrayed the belief that women were not allowed to participate in public sphere and that was influenced by cultural beliefs and practices that relegated the women to the household domain. Considering that the community observed their culture, patriarchy played a major role in contributing to the poor women's participation in projects.

Majority women did not hear much information on the projects since most of their time was spent in the household. However their men had better opportunity owing to their presence at the nearest Centres where a lot of information was being discussed by fellow men that either carried out businesses around there, relaxing or travelling.

Furthermore, in the community under the study men are regarded as leaders and decision makers and were assumed to know more than women. Based on that perception, the community therefore deemed it fit for the men to run the projects. The men also had more time to dedicate to the activities of the projects since they were not engaged in the household chores and that could explain their higher percentage at every level of project. From the findings therefore it can be implied that the women folk are marginalized when it comes to participation in project development.

\subsection{Chi-Square Test on Roles Performed by Project Stakeholders}

Table 7. Chi-Square Test on Roles Performed by Project Stakeholders.

\begin{tabular}{llll}
\hline & Value & df & Sig. (2-sided) \\
\hline Pearson Chi-Square & $24.368^{\mathrm{a}}$ & 5 & 0.000 \\
Likelihood Ratio & 26.718 & 5 & 0.000 \\
Linear-by-Linear Association & 17.889 & 1 & 0.000 \\
N of Valid Cases & 173 & & \\
\hline
\end{tabular}

From the chi-square statistics in table 7 , it can be observed that the roles played by the project beneficiaries in the planning and implementation of the development projects showed a significantly relationship on the basis of the gender of the respondents, $\chi 2(5, \mathrm{~N}=173)=24.368, \mathrm{p}=.000$. This implies that the variable gender and the roles played by project beneficiaries were statistically related $(p<.05)$. In view of the evidence from the analysis, the null hypothesis was rejected and the alternative claim was held true that there was a statistically significant relationship between the roles performed by the project beneficiaries in development projects in Baringo North Sub-County and their gender.

The implication of this finding is that the choice of any member to any leadership position or otherwise within the project was contingent upon the gender of the individual. The basis of the role assignment could have heavily been influenced by traditionally held views or ad hoc decisions that women are good home makers/ keepers and could therefore hold trust the projects' resources such as money- a reason why most of them held treasurers positions in the projects.

There was high disparity in the allocation of very important roles in the project, whereby the men occupied leadership positions and the women were allocated more of service support positions. This was unfair because the people who bear the highest brunt of poverty in society are women and children and yet when opportunities that could change their situations come up they are relegated to less powerful roles. It is unfair and there is need for project financiers to ensure that all people irrespective of their sex are included at all levels of project activities.

\section{Conclusions and Recommendations}

It was concluded that the level of participation in the projects by women is significantly low compared to that of males which is nearly one-half times that of the females. This was evident at the leadership positions where there were few women compared to men. The gender of an individual plays a greater role in placement in managerial positions within the projects.

Individual involvement at the various stages of project development did depend on the gender of an individual. The priority areas were given according to someone's gender and were informed by the cultural beliefs and practices of the community. This contributed to the gender inequality in the access to the projects and benefits accruing from them. It also relegated women to be recipients and that did not help much in reducing their poverty levels.

From the explanations of the respondents, the cultural practice and beliefs deterred women from leadership positions. Women were regarded as children and thought to think and reason like children hence they could not be allowed to hold positions of leadership and decision making. This belief locked out their voice in the projects yet some of them were to benefit women. This attitude and perception of the community about women had made women to be at the tail and when they lag behind many people suffer especially children. Research has shown that when women are poor, the effects are felt by everyone-men, boys, and girls. From observation of the study area, there were many poor women and their families were more vulnerable.

The study recommends that all community members irrespective of gender be allowed equal opportunity to be actively involved poverty reduction project. There is need for sensitization to reduce gender discrimination especially when it comes to selection into management positions. The study 
established that gender inclusion is still a huge issue in project implementation and suggests that a similar study could be replicated in other counties to be able to unpack challenges in project.

\section{References}

[1] Aliber, M. (2001). Chronic poverty and development policy. Cape Town: University of Western Cape.

[2] Buzan, Tony. (1995) The Mind Map Book: Radiant Thinking London: BBC Books

[3] Foeken, D. (2008) In side Poverty and Development in Africa, critical reflection on pro- poor policies. Brill, Lei Nairobi den, Netherlands.

[4] GoK (2010).Constitution of Kenya,Laws of Kenya 2010,Nairobi;National Council of Law Reporting
[5] GoK (2003). Millennium Development Goals; A Progress Report for Kenya. Nairobi: Government Printer.Kerlinger, F.N. (1983). Foundations of Behavioral Research. New York: Holt, Renehart and Winston.

[6] Kathuri, J. K. \& Pals, A. D. (1993). Introduction to Educational Research. Njoro, Educational Material Centre, Egerton University.

[7] Kerlinger, F.N. (1983). Foundations of Behavioral Research. New York: Holt, Renehart and Winston.

[8] Njeru,O,Gondi, (2005)Policy Based Approaches to Poverty Reduction in Kenya; strategies and civil society engagement, UNDP, Nairobi, Kenya.

[9] Omiti.J,Owino.W. and Odundo (2002).Poverty Reduction efforts in Kenya: Institutions, Capacity and Policy. Ipar discussion paper 033/2002,Nairobi,Kenya.

[10] World Bank, (2002). A World Bank Policy Research Report; Engendering Development through Gender Equality in Rights, Resources, and Voice. New York. Oxford University Press. 